Proc. Estonian Acad. Sci. Geol., 1998, 47, 3, 158-172

\title{
OANDU STAGE (CARADOC) IN CENTRAL NORTH ESTONIA
}

\author{
Linda HINTS
}

Institute of Geology at Tallinn Technical University, Estonia pst. 7, EE-0001 Tallinn, Estonia; e-mail: hints@gi.ee

Received 18 March 1998, in revised form 14 April 1998

\begin{abstract}
The late Caradoc Oandu Stage was studied in four core sections along the N-S profile in the central part of northern Estonia, and the composition of rocks and distribution of fossils in these cores were compared. The thinning of the Oandu sections in the southern, basinward direction has been caused by the gradual wedging out of the older strata. Supposedly, the Oandu Age rocks in northern Estonia have formed in the limits of restricted shelf during a short-living transgressive episode. Still, partial erosion of the early Oandu deposits can be suggested. Some biostratigraphical features, which may contribute to the correlation of sections from northern and southern Estonia belonging to different confacies belts, are emphasized. The litho- and biofacies specificity of the studied area reveals an essential change in environmental conditions in the Baltoscandian Palaeobasin during the late Caradoc due to both regional and global factors (e.g. transgression, regression, climatic change, and basin topography).
\end{abstract}

Key words: late Caradoc event, North Estonia, Oandu Stage.

\section{INTRODUCTION}

The discovery of fossiliferous marls and argillaceous limestones on the banks of the Oandu River in NE Estonia by A. Öpik in the 1930s was an essential amendment to the Ordovician stratigraphy since Schmidt's times, when the main principles of stage-level stratigraphy were worked out (Schmidt, 1881). These rocks, named the Oandu Beds (facies) by Öpik (1934), contain a diverse and rich association of fossils unknown in the older strata (Männil, 1958, 1960; Rõõmusoks, 1970, table 17; Põlma et al., 1988). The appearance of several taxa common with the North American Midcontinent is worthy of note (Jaanusson, 1973, 1979). In the Caradoc sequence of northern Estonia, the Oandu Beds represent lithologically and palaeontologically a stratigraphical marker level 
which separates the argillaceous limestones of the Keila Stage and micritic (aphanitic) limestones of the Rakvere Stage. In the modern stratigraphical literature the term "Oandu" marks a regional stage in the upper part of the Viru Series which is correlated with the middle part of the Dicranograptus clingani graptolite Zone (Fig. 1) (Männil, 1990).

\begin{tabular}{|c|c|c|c|c|c|}
\hline $\begin{array}{l}\text { B ritish } \\
\text { series }\end{array}$ & $\begin{array}{c}\text { Regional } \\
\text { series }\end{array}$ & $\begin{array}{l}\text { Regional } \\
\text { stage }\end{array}$ & $\begin{array}{l}\text { Graptolite } \\
\text { zone }\end{array}$ & $\begin{array}{l}\text { Chitinozoan } \\
\text { zone }\end{array}$ & $\begin{array}{l}\text { Formation and member } \\
\text { in North Estonia }\end{array}$ \\
\hline \multirow{4}{*}{ 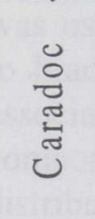 } & \multirow{4}{*}{$\stackrel{\Xi}{\leftrightarrows}$} & Rakvere & \multirow{4}{*}{$\begin{array}{c}\text { Dicranograptus } \\
\text { clingani }\end{array}$} & \multirow{2}{*}{$\begin{array}{c}\text { Fungochitina } \\
\text { fungiformis }\end{array}$} & Rägavere Fm. \\
\hline & & \multirow{2}{*}{ O andu } & & & Tõrremägi $\mathrm{M} b$. \\
\hline & & & & \multirow{2}{*}{$\begin{array}{l}\text { Spinachitina } \\
\text { cervicornis }\end{array}$} & Vasalemma $<$ Hirmuse Fm \\
\hline & & Keila & & & Kahula Fm. \\
\hline
\end{tabular}

Fig. 1. Correlation of the stratigraphical units represented in the studied sections (by Nõlvak, 1997).

In North Estonia the Oandu Stage is represented by argillaceous limestones and marls of the Hirmuse Formation, overlain by relatively pure limestones of the Tõrremägi Member of the Rägavere Formation (Männil \& Rõõmusoks, 1984) (Fig. 1). The Hirmuse Formation corresponds to the main part of Öpik's (1934) Oandu Beds (three lowermost units, $\mathrm{O}_{1-3}$; Männil, 1960) and the Tõrremägi Member to the uppermost part of these beds $\left(\mathrm{O}_{4}\right)$. Exceptionally, in NW Estonia the Oandu Stage consists of the skeletal limestones and organic buildups of the upper part of the Vasalemma Formation (Wasalemm'sche Schicht by Schmidt, 1881). The upper Vasalemma Formation and the Hirmuse Formation are considered contemporaneous due to common species (see Rõõmusoks, 1970) and a similar stratigraphical position. Upwards both units are succeeded by the Tõrremägi Member (Põlma et al., 1988). Still, some authors (Jaanusson, 1945; Resheniya, 1978) consider the beds belonging to the Hirmuse Formation younger than the Vasalemma Formation.

The purpose of this study is to explain the specificity of the Oandu Age sequence in the central part of North Estonia (between the settlements of Kehra and Ardu) by comparing the composition of rocks and distribution of fossils in four core sections. Here the thickness of the sequence decreases rapidly in southern, basinward direction. An attempt is made to find out some new criteria for the correlation of Oandu sections from different confacies belts (Fig. 2). The determination of the Oandu Stage in the southern, Scandinavian confacies belt is under discussion up to now. This complicates the understanding of geological events occurring in the Baltic Basin during the late Caradoc identified as the differentiation stage of the basin (Nestor \& Einasto, 1997). 


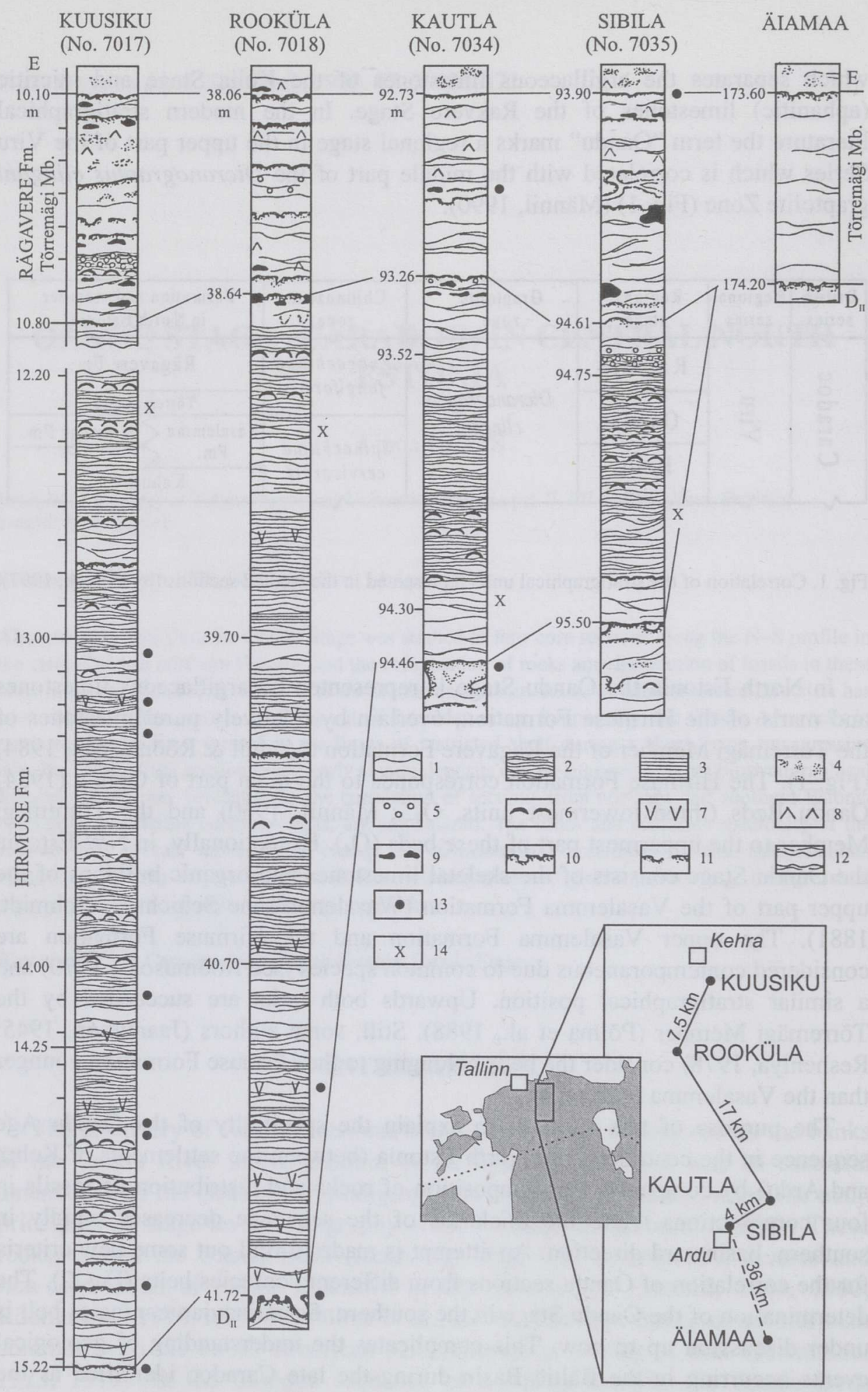


The material presented here was derived from four cores: Kuusiku (No. 7017), Rooküla (No. 7018), Kautla (No. 7034), and Sibila (No. 7035) (Fig. 2). The distance between the farthest boreholes is about $25 \mathrm{~km}$. The cores were drilled in the 1970s by the Geological Survey of Estonia. The samples collected for the study of macrofossils cover practically the whole core sequence except for the northernmost, Kuusiku drillcore, where core from the interval of 10.80-12.20 m has got lost. Altogether more than 230 samples were studied; the thickness of samples varied from 2 to $16 \mathrm{~cm}$. Fossils were studied on the bedding planes. In case of marls and clays fossils were washed out in water or hydrogen peroxide was used for separating them from the rock matrix. Main attention was paid to brachiopods, but several other fossils were identified as well. The rich association of bryozoans has not been studied at all up to now. Partly data on the composition of rocks (content of terrigenous and bioclastic material) and on the distribution of some chitinozoans were taken from the unpublished databases by L. Põlma and R. Männil, respectively. Certain aspects of the studied cores have been discussed in several publications (Männil, 1976; Põlma et al., 1988, pp. 75, 76 ; Hints, 1998). The collection of samples and additional materials to this paper are housed in the Institute of Geology at Tallinn Technical University.

\section{GEOLOGICAL SETTING}

In the studied four sections, as in most part of northern Estonia, the Oandu Stage comprises the Hirmuse Formation and the Torremägi Member of the Rägavere Formation (Männil \& Rõõmusoks, 1984; Hints \& Meidla, 1997). The sections located on the N-S profile reveal a rapid southward decrease in the thickness (from 5.12 to $1.61 \mathrm{~m}$ ) of the Oandu sequence (see also Rõõmusoks, 1970, figs. 53, 54) due to wedging out of part of the Hirmuse Formation. So, to the south of the study area, in the Äiamaa core, the stage is represented only by its upper unit (Tõrremägi Member) (Fig. 2). The comparison of the northern cores, Kuusiku and Rooküla, with the Kautla and Sibila cores shows differences not only in their thickness (about three times) but also in the composition of rocks, i.e. in the amount of terrigenous and bioclastic material (Figs. 2-5). In the

Fig. 2. The Oandu Stage in the sections along the Kuusiku-Äiamaa line; consists of the Hirmuse Formation and Tõrremägi Member of the Rägavere Formation. The location of drillcores is shown in the right lower corner. The logs represent sedimentary structures (simplified) from the core surface. Key: 1 , more or less argillaceous limestones; 2 , marls, predominantly massive; 3 , laminated marls and argillaceous limestones with some content of fine sand and silt; 4 , micritic limestones with pyrite patterns; 5 , burrows; 6 , brachiopod coquinas; 7 , frequent occurrence of bryozoan fragments; 8 , kukersite kerogen; 9, carbonate clasts with dark impregnation; 10, discontinuity surfaces with pyrite impregnation; 11 , probable discontinuity surface; 12 , interval with loss of core; 13, the photos in Pls. I and II; 14, the level with some content of mica (biotite) in the rock. The dotted line on the map marks the approximate boundary of the North Estonian and Scandinavian confacies belts. $\mathrm{D}_{\mathrm{II}}$, Keila Stage; E, Rakvere Stage. 
ROOKÜLA

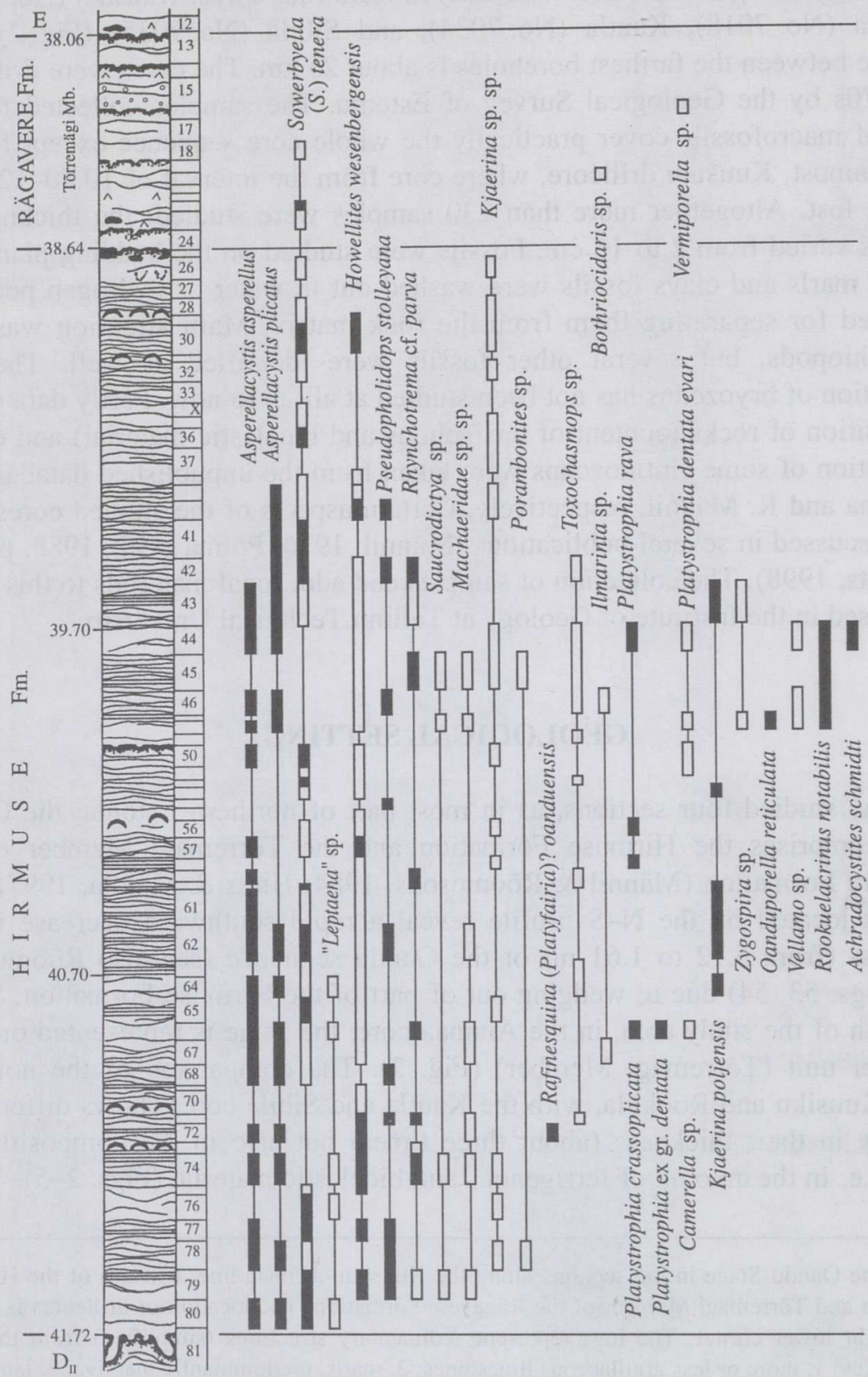

Fig. 3. Distribution of selected species in the Rooküla core. See Fig. 2 for key. To the right of the logs the sampling intervals and numbers of samples are shown; the empty squares mark intervals where the specimens were identified at the genus level. 


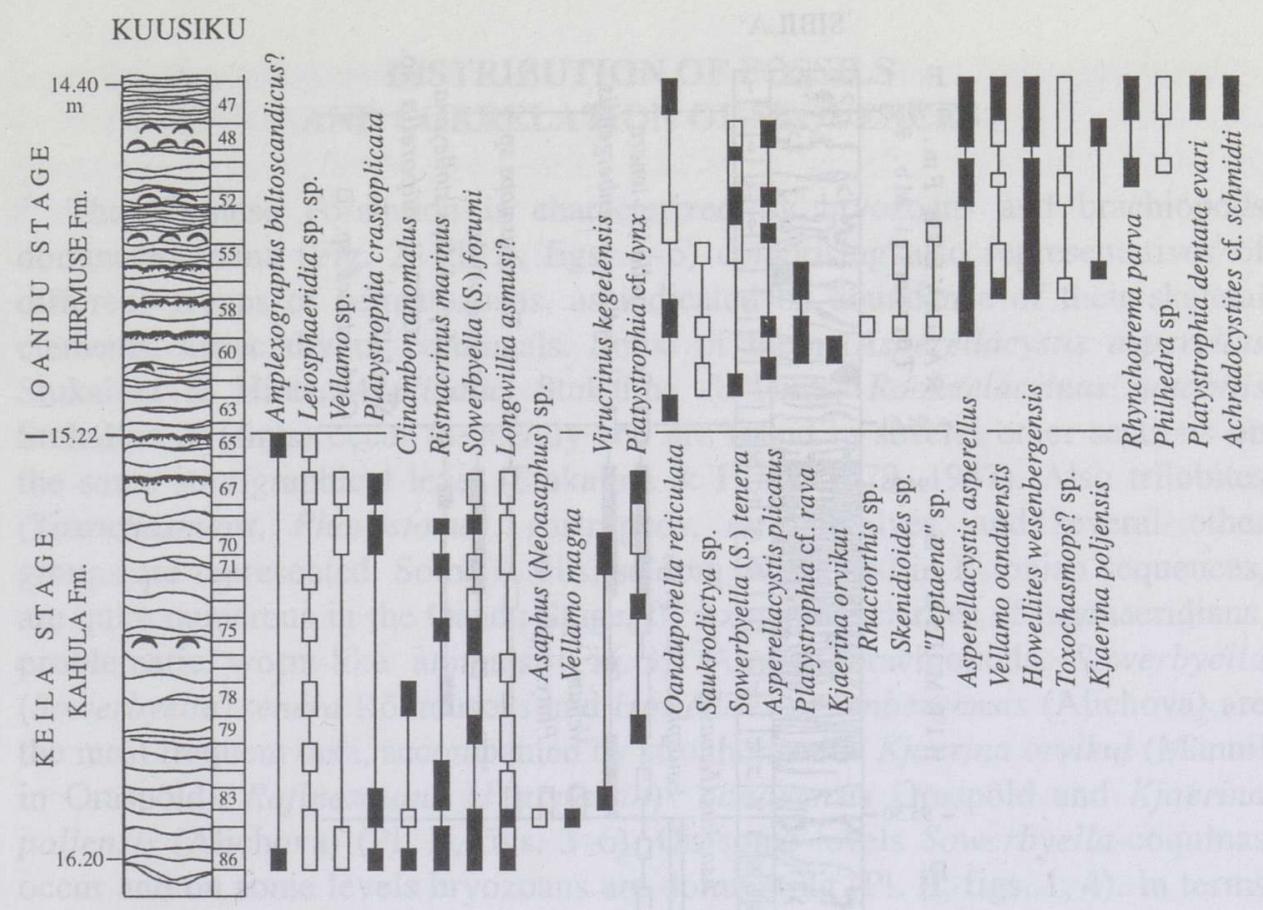

Fig. 4. Distribution of selected species in the boundary interval of the Keila and Oandu stages in the Kuusiku core. See Figs. 2 and 3 for key.

two first cores the Hirmuse Formation consists of argillaceous marls and carbonate clays intercalating with more or less argillaceous limestones. The content of bioclastic material (brachiopods, bryozoans, etc.; Pl. I, fig. 6) varies bed by bed forming $20-40 \%$ in the rock. The occurrence of thin $(3-5 \mathrm{~cm})$ laminated marls and limestones with some fine sand (Pl. I, figs. 3, 4) on different stratigraphical levels is characteristic only of the Kuusiku and Rooküla sections (Fig. 2). The content of terrigenous material is variable (from $9 \%$ to about $80 \%$; mean about $35 \%$; L. Põlma's data from 22 samples), but two relatively more terrigenous intervals can be observed. In the lower half of the Hirmuse Formation the content of the terrigenous material (fine silt and clay) is highest $-77 \%$ and $58 \%$, respectively, at a depth of $14.25 \mathrm{~m}$ in the Kuusiku core and at a depth of $40.7 \mathrm{~m}$ in the Rooküla core. In the upper half of the formation the most clayey beds occur at a depth of $13.0 \mathrm{~m}$ (terrigenous material forms $55 \%$ of the rock) in the Kuusiku core and at 39.7 m (terrigenous material 73\%) in the Rooküla core.

In the Kautla and Sibila cores the Hirmuse Formation consists also of argillaceous marls, clays, and limestones, but with lower contents of bioclastic (about 5-25\%) and terrigenous material (does not reach 60\%) in comparison with the northernmost cores described above. The most clayey rocks contain $45-51 \%$ terrigenous material and they occur in the middle part of the Hirmuse 


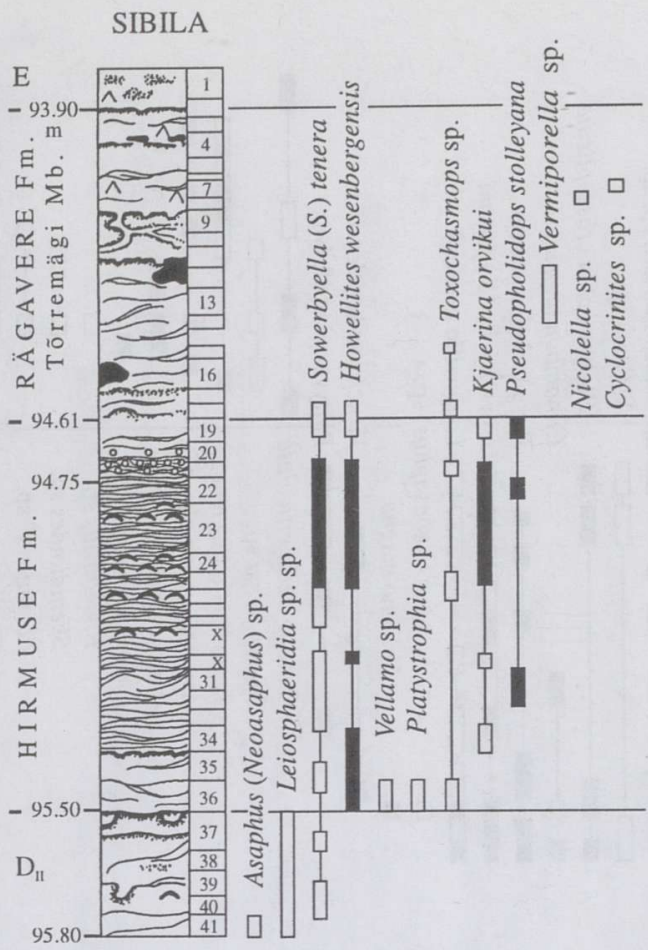

Fig. 5. Distribution of selected species in the Sibila core. See Figs. 2 and 3 for key.

Formation. Tentatively three subdivisions - the lower argillaceous limestone $\left(\mathrm{O}_{1}\right.$ by Männil, 1960), marls $\left(\mathrm{O}_{2}\right)$, and upper argillaceous limestone $\left(\mathrm{O}_{3}\right)$ can be distinguished. Such type of sections is described from NE Estonia where the type sections of the Oandu Stage and Hirmuse Formation are located (Männil, 1960; Rõõmusoks, 1970).

In the studied sections the upper part of the Oandu Stage is represented by relatively pure micro- to cryptocrystalline limestones of the Tõrremägi Member in a thickness from $0.53 \mathrm{~m}$ (in the Kautla core) to $0.71 \mathrm{~m}$ (in the Sibila core) (Figs. 2, 4, 5). The member is characterized by the domination of fragments of dasyclad algae Vermiporella among the bioclastic component. So, in the Rooküla core the bioclastic material forms $32 \%$ of the rock (sample at a depth of $38.21-38.27 \mathrm{~m}$ ) and of that fragments of algale (size $>1 \mathrm{~mm}$ ) make $76 \%$ (unpublished data by L. Põlma). The corresponding values for the Sibila core (samples from $94.40-94.50 \mathrm{~m}$ ) are $18 \%$ and $80 \%$. A bed of Vermiporellalimestone (10-20 cm thick) occurs in the lower half of the member. Pyritized discontinuity surfaces, on some levels with carbonate clasts (Pl. I, fig. 8) above them, and the occurrence of kukersite kerogen in argillaceous bedding planes or in the burrows characterize the Tõrremägi Member (Fig. 2). 


\section{DISTRIBUTION OF FOSSILS AND CORRELATION OF SEQUENCES}

The Hirmuse Formation is characterized by bryozoans and brachiopods dominated fauna (Fig. 2; Pl. II, figs. 1-6) comprising also representatives of different groups of pelmatozoans, as indicated by abundance of their skeletal elements, especially of columnals. Some of them (Asperellacystis asperellus Stukalina \& Hints, A. plicatus Stukalina \& Hints, Rookuelacrinus notabilis Stukalina \& Hints) occur frequently and are found in several other sections on the same stratigraphical level (Stukalina \& Hints, 1979, 1987). Also trilobites (Toxochasmops, Pharostoma), gastropods, rare bivalves, and several other groups are represented. Some fossils, seldom mentioned in Estonian sequences, are quite numerous in the Oandu Stage, for example, sclerites of machaeridians, problematic worm-like animals (Fig. 3). Among brachiopods, Sowerbyella (Sowerbyella) tenera Rõõmusoks and Howellites wesenbergensis (Alichova) are the most frequent taxa, accompanied by strophomenids Kjaerina orvikui (Männil in Oraspõld), Rafinesquina (Platyfairia)? oanduensis Oraspõld and Kjaerina poljensis (Alichova) (Pl. II, figs. 3-6). On some levels Sowerbyella-coquinas occur and on some levels bryozoans are dominating (Pl. II, figs. 1, 4). In terms of brachiopod communities, the Hirmuse Formation is characterized by the Sowerbyella-Howellites community, which is considered as a typical Caradoc shallow-water community in different basins (Cocks \& McKerrow, 1978; Jaanusson, 1984).

The Kuusiku core differs from the others in the occurrence of some unusual for North Estonia brachiopods such as Skenidioides and Rhactorthis and in the absence of Howellites wesenbergensis in the lowermost part of the Hirmuse Formation (Fig. 4). Up to now Skenidioides has been found in South Estonian sections (Hints \& Meidla, 1997, fig. 51). The oldest representatives of Rhactorthis (Hints, 1973) have also been identified from this area, in places together with Skenidioides, from the argillaceous limestones and marls of late Keila (?) and Oandu ages. The above-mentioned $H$. wesenbergensis appears in many sections just above the lower boundary of the Oandu Stage; in the stratotype area in Northeast Estonia it occurs even in the cavities of the boundary discontinuity surface (Põlma et al., 1988, fig. 36). In the lowermost part of the Hirmuse Formation in the Kuusiku core also a distinct association of chitinozoans appears (with "Spinachitina"-group taxa), not established in other three sections (unpublished data by R. Männil). The above data allow us to suppose that the lowermost part (about $30-40 \mathrm{~cm}$ ) of the Hirmuse Formation has no contemporaneous beds in the southern sections. These beds contains also several discontinuity surfaces ( $\mathrm{Pl}$. I, fig. 7) which have not been found in the Rooküla core.

The most part of the Hirmuse Formation in the Kuusiku and Rooküla cores is characterized by a quite similar faunal association. The shelly fossils are missing 
in laminated silty interlayers, where sometimes occur only burrows filled with clay (PI. I, figs. 3, 4). A different degree of alteration of brachiopod valves (external sculpture or other diagnostic morphological structures are partly destroyed; Pl. II, figs. 4-6) complicates the species-level identification of specimens and indicates a variable wave activity and some transportation of shelly material.

In the two southern sections, Kautla and Sibila, the faunal association of the Hirmuse Formation is less diverse than that described above (Fig. 5). It is best comparable with the fauna of the upper half of the formation in the Kuusiku and Rooküla cores. But we have no sufficient data on macrofossils for such correlation. For the correlation of cores the occurrence of mica (biotite) in some samples is used. The little plates of biotite were detected under microscope during the palaeontological study of samples. Such samples occur $0.5-1.5 \mathrm{~m}$ below the upper boundary of the Hirmuse Formation and supposedly mark a roughly synchronous level. If this is true, then the lower half of the mentioned formation is wedging out at a distance of about $17 \mathrm{~km}$, between Rooküla and Kautla. The occurrence of biotite may be a result of redeposition of some $\mathrm{K}$-bentonite. Mica has been cited also as an indicator of littoral sedimentation (Pettijohn, 1949, p. 96).

Most of the shelly fauna which existed during the early Oandu time in the North Estonian confacies belt (Fig. 2) did not survive the substitution of calcareous clayey deposits (Hirmuse Formation) by relatively pure carbonate muds (Tõrremägi Member). The late Oandu biota consists mainly of dasyclad algae with sparse macrofauna, new, common with the Rakvere Stage taxa among chitinozoans (Nõlvak \& Grahn, 1993), and ostracodes (Meidla, 1996).

\section{ON THE BOUNDARIES OF THE OANDU STAGE}

The lower boundary of the Oandu Stage and Hirmuse Formation coincides with the pyritized discontinuity surface on the top of argillaceous limestones of late Keila age (Fig. 2). This surface is perforated by burrows (diameter $1-4 \mathrm{~mm}$ ) and cavities, which reach up to $20 \mathrm{~cm}$ down into the Keila age rocks. In the Kuusiku and Rooküla sections these cavities are not so deep as in the southern Kautla and Sibila cores (Pl. I, figs. 1,2). In the last core the relicts of the oldest Oandu sediments are preserved only in the cavities of the boundary discontinuity surface (Fig. 2) (see also Ainsaar, 1995).

By the end of the Keila time most of the early Caradoc biotas had become extinct and representatives of a new, rich and diverse fauna appeared at the beginning of the Oandu time (Rõõmusoks, 1970; Põlma et al., 1988; Hints et al., 1989). The acritarch flora and chitinozoan fauna (?) are an exception; these are characterized by an extreme diversity low during the Oandu time (Kaljo et al., 1996). The boundary beds between the Keila and Oandu stages have been studied 
in detail in the Kuusiku core (Fig. 4). Below the boundary discontinuity R. Männil (unpublished data) has identified the graptolite Amplexograptus cf. fallax which should be conspecific with $A$. baltoscandicus Jaanusson, a species characteristic of the Haljala and Keila stages (Jaanusson, 1995). There occur also several other species - "Horderleyella" oanduensis Hints, Longvillia asmusi (Verneuil), Asaphus (Neoasaphus) sp., and others indicative of Keila age. Frequent occurrence of a large acritarch Leiosphaeridia in samples below the boundary discontinuity is notable. The boundary between the Keila and Oandu stages can be determined quite easily in North Estonian sections by both lithological and palaeontological criteria. It is stressed by the lack of the oldest Oandu and possibly latest Keila deposits in many sections. In this sense the discussed boundary is similar to the boundary between the Kukruse and Idavere stages in northern Estonia where also the oldest part of the Idavere Stage is missing (Hints et al., 1994).

The supposedly oldest Oandu age rocks in the Kuusiku core comprise fossils (see above) which may be useful for the correlation of North and South Estonian sequences belonging to different confacies (Fig. 2) and being characterized by notably different faunal associations. In South Estonia the brachiopods Rhactorthis kaagverensis, Skenidioides sp., Platystrophia rava, and Oanduporella sp. appear, as in North Estonia, close to the level of the disappearance or sharp decrease in the frequency of the acritarch Leiosphaeridia (Hints \& Meidla, 1997, fig. 51). This acritarch is far from being a sufficient criterion for the determination of the lower boundary of the Oandu Stage. Still, the interval of changes in its frequency in South Estonia deserves special attention. Some preliminary data, obtained during the study of macrofossils from the sections of South Estonia, show changes (in frequency or species composition) among the "Spinachitina"-group chitinozoans on the same level. However, in the sense of chitinozoan zonation (Nõlvak \& Grahn, 1993), the Oandu Stage corresponds to the uppermost part of the Spinachitina cervicornis Zone and lower part of the Fungochitina fungiformis Zone (Fig. 1). The boundary between these zones coincides roughly with the boundary between the Hirmuse and Rägavere formations (Nõlvak, 1997).

The upper boundary of the Oandu Stage coincides, according to Öpik's interpretation, with the upper boundary of the Tõremägi Member (Pl. I, fig. 5) (Männil, 1958, 1960; Rõõmusoks, 1970; Hints \& Meidla, 1997). Sowerbyella (S.) cf. tenera, Kjaerina poljensis, and some other species are noted (Rõõmusoks, 1970 , p. 320) as taxa indicating the Oandu age of the Tõrremägi Member. In the studied cores the exact age of this unit cannot be determined by macrofossils. However, on the basis of many other core sections we may conclude that the chitinozoans (Nõlvak \& Grahn, 1993), ostracodes (Meidla, 1996, p. 202, table 9), and also scolecodonts (Hints, 1998) are represented in the Torremägi Member mainly by the species common with the Rakvere Stage. This complicates the establishing of the upper boundary of the Oandu Stage outside the distribution 
area of the Hirmuse Formation and Tõrremägi Member. The level of the appearance of zonal chitinozoans and a new association of ostracodes should be considered as a possible boundary between the Oandu and Rakvere stages, which can be defined more unambigously in facially different sections.

\section{DISCUSSION}

The discussed time interval falls into the beginning of the differentiation stage in the development of the Baltoscandian Basin (Põlma, 1982; Nestor, 1990; Nestor \& Einasto, 1997). The significant decrease in the thickness of the Oandu sequence occurring over a short distance, as well as the lithological and faunal differences between the studied sections, point to relatively fast changes in environments during a rather short period in the limits of the North Estonian confacies belt. The transgressive nature of the Oandu sequence is expressed by gradual widening of the distribution area of younger deposits. The periodic increase in the influx of terrigenous material and possible partial erosion of older deposits suggest oscillation of the sea level during the predominantly transgressive episode. These changes were seemingly associated with changes in climate, which became more arid at the end of the Oandu time, as indicated by the increase in carbonate mud (see Nestor \& Einasto, 1997) in the rock (in the Tõrremägi Member). The wedging out of lower parts of the Hirmuse Formation in the offshore direction is possibly influenced by the formation of a shoal in Central Estonia (see Männil, 1966, figs. 43, 61; Nestor, 1990; Kõrts et al., 1990) due to regional tectonic movements and changes in the sea bottom topography. The fine terrigenous material deposited in the early Oandu time in the restricted

\section{PLATE I}

Fig. 1. Discontinuity surface with burrows (A) and cavities (B) on the boundary between the Keila and Oandu stages, Kautla drillcore, depth $94.46 \mathrm{~m}, \times 1$.

Fig. 2. The same discontinuity surface, Rooküla drillcore, depth $41.70 \mathrm{~m}, \times 1$.

Fig. 3. Cross-section of a bed of laminated limestone, Kuusiku drillcore, depth $14.3 \mathrm{~m}$. The light spots - burrows filled with clay. Sample from L. Põlma's collection, $\times 1$.

Fig. 4. Cross-section of a bed of laminated limestone with the deformation structures in the upper part. Kuusiku drillcore, depth 14.09 m. Sample from L. Põlma's collection, $\times 1$.

Fig. 5. Discontinuity surface on the boundary between the Oandu and Rakvere stages, Sibila drillcore, depth $93.90 \mathrm{~m}$. Sample from L. Põlma's collection, $\times 1$.

Fig. 6. Cross-section of the relatively pure limestone with fragments of brachiopod valves and bryozoans, Rooküla drillcore, depth $41.10-41.12 \mathrm{~m}, \times 1$.

Fig. 7. Discontinuity surface with borings of Trypanites, Kuusiku drillcore, depth $14.98 \mathrm{~m}, \times 1.5$.

Fig. 8. Discontinuity surface and carbonate clasts in the Kautla drillcore, depth $93.03 \mathrm{~m}, \times 1$. 

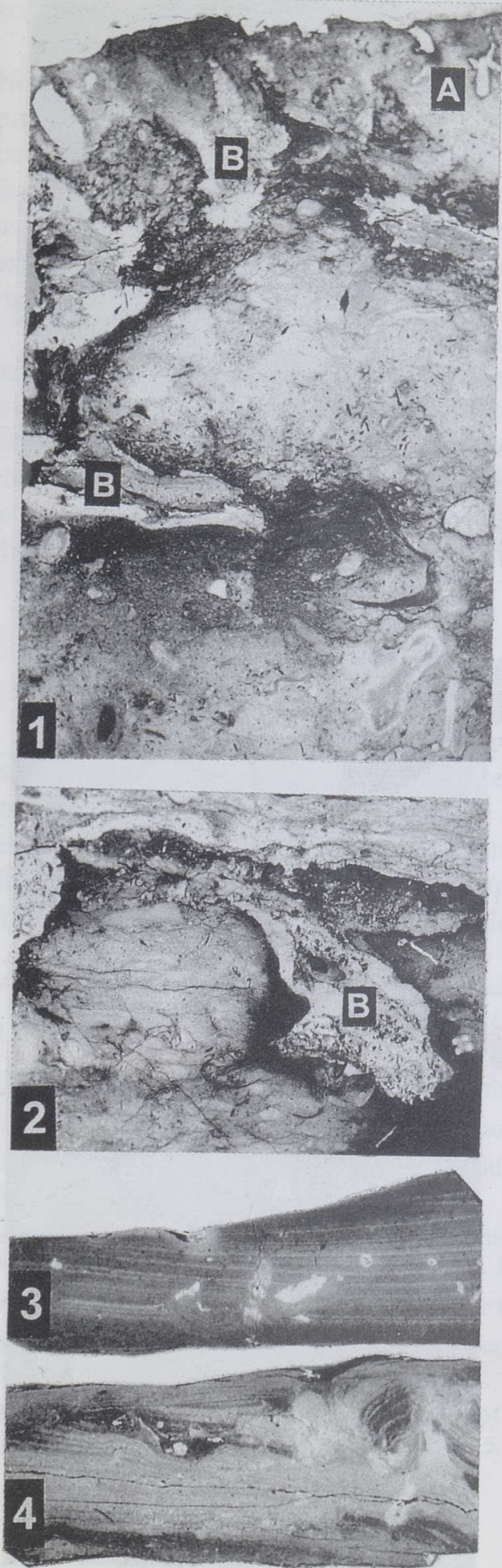

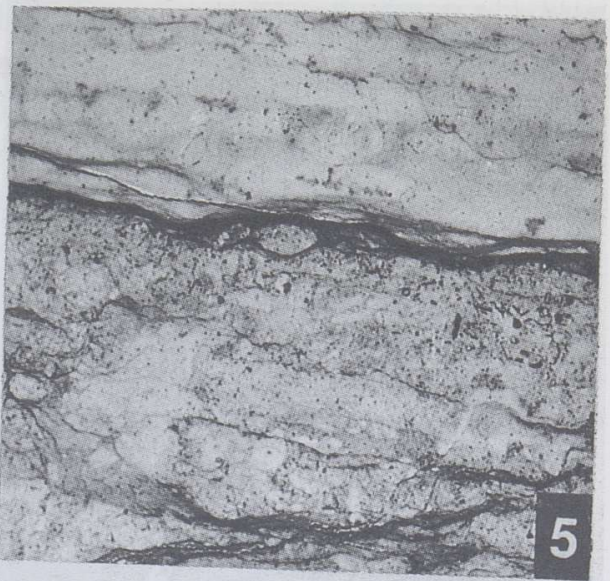

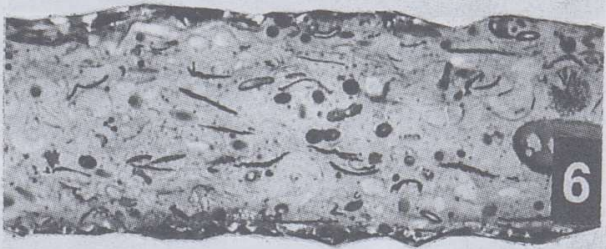
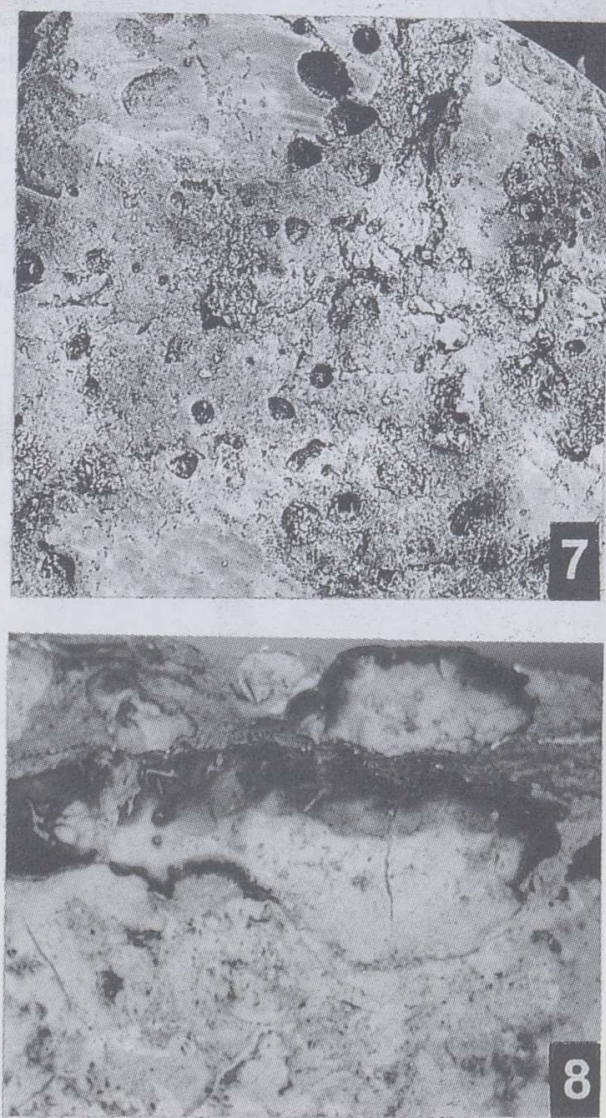

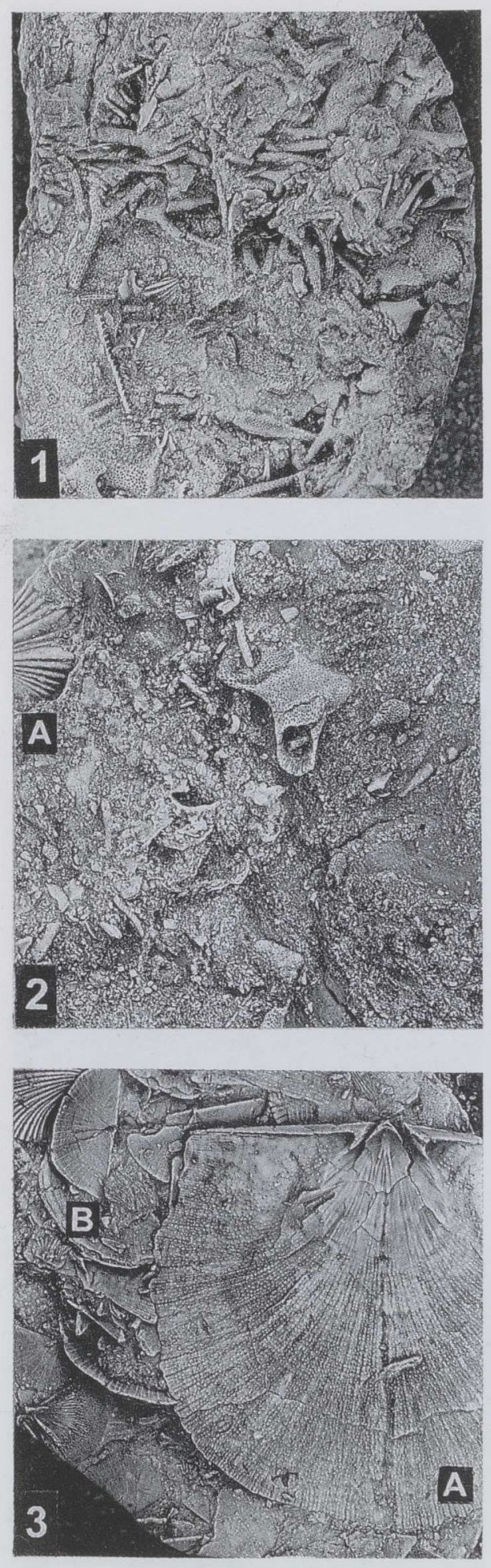
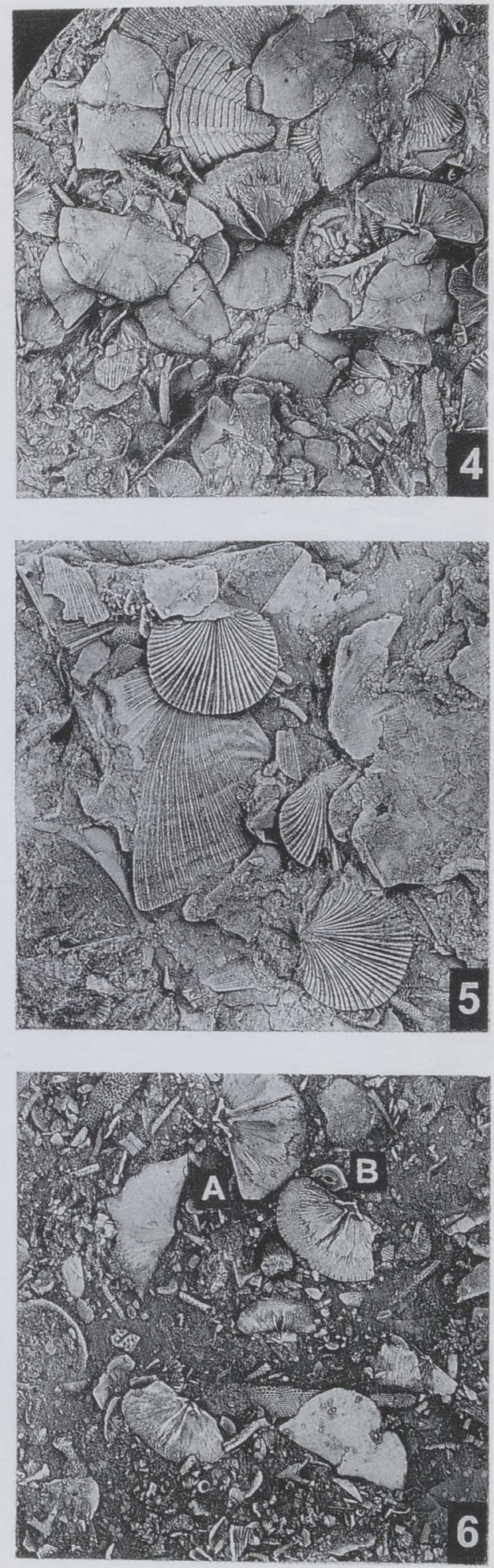
shelf area was probably partly washed out southwards. Locally the environments of nonsedimentation, as proposed by Ainsaar (1995) for the late Keila time, seemingly existed also in northern Estonia during the early Oandu time.

The existence of a shoal may account for the faunal differences between North and South Estonia which belong to different confacies belts. The shoal was presumably connected to the areas in northwestern Estonia where carbonate buildups (Vasalemma Formation) formed, but to check this hypothesis is beyond the scope of this study. The restricted contact of the onshore and offshore faunas was caused by inhibited water exchange between onshore and offshore areas expressed, for example, by the rarity of siculae and proximal parts of graptolite rhabdosomes in North Estonia, as pointed out by Männil (1976).

The development of facies and faunas during the late Keila and Oandu times in the East Baltic, including northern Estonia, shows some similarity with the situation in North America. Beside the invasion of North American faunal elements into the Baltic Basin, we may suggest roughly contemporaneous changes in climate and sea level (see Patzkowsky et al., 1997). The global nature of the clingani-age events in the Ordovician basins seems to be underestimated in chronostratigraphy.

\section{ACKNOWLEDGEMENTS}

The author is grateful to D. Kaljo for reading the early version of the text and many valuable suggestions. Thanks are extended to $G$. Baranov who made the copies of the photos and O. Hints for help with preparing the figures. The research was supported by grant No. 3516 of the Estonian Science Foundation. This is a contribution to the International Geological Correlation Programme Project No. 410: The Great Ordovician Biodiversification Event (GOBE).

\section{PLATE II}

Figs. 1-6. Bedding planes with different fossils in the Kuusiku drillcore.

Fig. 1. Argillaceous limestone with abundant bryozoan fragments, depth $15.20 \mathrm{~m}, \times 1.5$.

Fig. 2. Organodetrital argillaceous limestone with few large shelly fauna, depth $13.2 \mathrm{~m}$. A Platystrophia ex. gr. dentata, $\times 1.5$.

Fig. 3. Kjaerina poljensis (A - interior of the pedicle valve) together with valves of Sowerbyella (B) and Howellites (in the upper left corner), depth $14.5 \mathrm{~m}, \times 1.5$.

Fig. 4. The Sowerbyella-coquina, depth $14.52 \mathrm{~m}, \times 1.4$.

Fig. 5. Bedding plane with fragments of strophomenids and Howellites wesenbergensis (exterior of the dorsal valve), depth $13.30 \mathrm{~m}, \times 1.5$.

Fig. 6. Bedding plane with numerous valves of Sowerbyella (A) and a stem columnal of Asperellacystis asperellus (B), depth $13.04 \mathrm{~m}, \times 1.5$. 
Ainsaar, L. 1995. Terrigeenne materjal veetaseme muutuste kajastana Lõuna-Eesti ordoviitsiumis. In Liivimaa geoloogia (Meidla, T., Jõeleht, A., Kalm, V. \& Kirs, J., eds.). Tartu Ülikooli Kirjastus, Tartu, 51-59.

Cocks, L. R. M. \& McKerrow, W. S. 1978. Ordovician. In The Ecology of Fossils. An Illustrated Guide (McKerrow, W. S., ed.). Duckworth, London, 62-92.

Hints, L. 1973. New Orthacean Brachiopods from the Middle Ordovician of the East Baltic Area and Sweden. ENSV TA Toim. Keem. Geol., 22, 3, 248-256 (in Russian).

Hints, L. \& Meidla, T. 1997. Oandu Stage. In Geology and Mineral Resources of Estonia (Raukas, A. \& Teedumäe, A., eds.). Estonian Academy Publishers, Tallinn, 76-79.

Hints, L., Meidla, T. \& Nõlvak, J. 1994. Ordovician sequences of the East European Platform. Geologija, 17, 58-63.

Hints, L., Meidla, T., Nõlvak, J. \& Sarv, L. 1989. Some specific features of the Late Ordovician evolution in the Baltic basin. Proc. Acad. Sci. ESSR. Geol., 38, 2, 83-87.

Hints, O. 1998. Late Viruan (Caradoc) polychaete jaws from North Estonia and St. Petersburg Region. Acta Palaeontol. Pol., 43, 3, 471-516.

Jaanusson, V. 1945. Über die Stratigraphie der Viru-resp. Chasmops-Serie in Estland. Geol. Fören. Stockh. Förh., 67, 2, 212-224.

Jaanusson, V. 1973. Ordovician articulate brachiopods. In Atlas of Palaebiogeography (Hallam, A., ed). Elsevier, Amsterdam, 19-25.

Jaanusson, V. 1979. Ordovician. In Treatise on Invertebrate Palaeontology. Vol. A. IntroductionBiogeography and Biostratigraphy (Moore, R. C., ed). Geol. Soc. Amer. and Univ. Kansas Press, A136-A166.

Jaanusson, V. 1984. Ordovician benthic macrofaunal association. In Abstracts of the Ordovician System (Bruton, D. L., ed.). Palaeont. Contr. Univ. Oslo, 295, 127-139.

Jaanusson, V. 1995. Confacies differentiation and upper Middle Ordovician correlation in the Baltoscandian basin. Proc. Estonian Acad. Sci. Geol., 44, 2, 73-86.

Kaljo, D., Nõlvak, J. \& Uutela, A. 1996. More about Ordovician microfossil diversity patterns in the Rapla section, northern Estonia. Proc. Estonian Acad. Sci. Geol., 45, 3, 131-148.

Kõrts, A., Einasto, R., Männil, R. \& Radionova, E. 1990. Calcareous algae. In Field Meeting Estonia 1990. An Excursion Guidebook (Kaljo, D. \& Nestor, H., eds.). Estonian Academy of Sciences, Tallinn, 97-100.

Männil, R. 1958. Stratigrafiya i paleogeografiya Oanduskogo gorizonta ( $\left.\mathrm{D}_{\mathrm{III}}\right)$. In Tezisy dokladov nauchnoj sessii, posvyashchennoj 50-oj godovshchine so dnya smerti akad. F. B. Shmidta. Tallinn, 34-37 (in Russian).

Männil, R. 1960. The stratigraphy of the Oandu ("Vasalemma" Stage). ENSV TA Geol. Inst. Uurimused, 5, 89-122 (in Russian).

Männil, R. 1966. Evolution of the Baltic Basin During the Ordovician. Valgus, Tallinn (in Russian).

Männil, R. 1976. Distribution of graptolites in the Ordovician carbonate rocks of the east Baltic area. In Graptolites and Stratigraphy (Kaljo, D. \& Koren, T., eds.). Valgus, Tallinn, 105-118 (in Russian).

Männil, R. 1990. The Ordovician of Estonia. In Field Meeting Estonia 1990. An Excursion Guidebook (Kaljo, D. \& Nestor, H., eds). Estonian Academy of Sciences, Tallinn, 11-20.

Männil, R. \& Rõõmusoks, A. 1984. A revision of the lithostratigraphic subdivision of the Ordovician of North Estonia. In Stratigrafiya drevnepaleozoiskikh otlozhenij Pribaltiki (Männil, R. \& Mens, K., eds). Institute of Geology, Tallinn, 52-62 (in Russian).

Meidla, T. 1996. Late Ordovician Ostracodes of Estonia. Fossilia Baltica, 2. Tartu University Press.

Nestor, H. 1990. Basin development and facies models. In Field Meeting Estonia 1990. An Excursion Guidebook (Kaljo, D. \& Nestor, H., eds.). Estonian Academy of Sciences, Tallinn, 33-36.

Nestor, H. \& Einasto, R. 1997. Ordovician and Silurian carbonate sedimentation basin. In Geology and Mineral Resources of Estonia (Raukas, A. \& Teedumäe, A., eds.). Estonian Academy Publishers, Tallinn, 192-204. 
Nõlvak, J. 1997. Ordovician. Introduction. In Geology and Mineral Resources of Estonia (Raukas, A. \& Teedumäe, A., eds.). Estonian Academy Publishers, Tallinn, 52, 54, 55.

Nõlvak, J. \& Grahn, Y. 1993. Ordovician chitinozoan zones from Baltoscandia. Rev. Palaeobot. Palynol., 79, 245-269.

Öpik, A. 1934. Über Klitamboniten. Publ. Geol. Inst. Univ. Tartu, 39.

Patzkowsky, M. E., Slupik, L. M., Arthur, M. A., Pancost, R. D. \& Freeman, K. H. 1997. Late Middle Ordovician environmental change and extinction: Harbinger of the Late Ordovician or continuation of Cambrian patterns? Geology, 10, 911-914.

Pettijohn, F. J. 1949. Sedimentary Rocks. Harper \& Brothers, New York.

Põlma, L. 1982. Comparative Lithology of the Ordovician Carbonate Rocks in Northern and Middle East-Baltic. Valgus, Tallinn (in Russian).

Põlma, L., Sarv, L. \& Hints, L. 1988. Lithology and Fauna of the Type Sections of the Caradoc Series in North Estonia. Valgus, Tallinn (in Russian).

Resheniya..., 1978. Resheniya Mezhvedomstvennogo regional'nogo stratigraficheskogo soveshchaniya po razrabotke unifitsirovannykh stratigraficheskikh skhem Pribaltiki 1976 g. s unifitsirovannymi stratigraficheskimi korrelyatsionnymi tablitsami. Litovskij NIGRI, Leningrad.

Rõõmusoks, A. 1970. Stratigraphy of the Viruan Series (Middle Ordovician) in Northern Estonia I. Valgus, Tallinn (in Russian).

Schmidt, F. 1881. Revision der ostbaltischen silurischen Trilobiten nebst geognostischer Übersicht des ostbaltischen Silurgebiets. Abt. I: Phacopiden, Cheiruriden und Encrinuriden. Mém. Acad. Sci. St. Pétersb., sér. VII, XXX, 1.

Stukalina, G. \& Hints, L. 1979. New finds of Echinoderms in the Upper Viruan deposits of North Estonia. ENSV TA Toim. Geol., 28, 1, 1-10 (in Russian).

Stukalina, G. \& Hints, L. 1987. Columnals of Echinoderms with condylial articulation (the Ordovician of the Baltic area). Proc. Acad. Sci. ESSR. Geol., 36, 3, 104-112 (in Russian).

\section{OANDU LADE PÕHJA-EESTI KESKOSAS}

\section{Linda HINTS}

On esitatud ülevaade Oandu lademe (Hilis-Caradoc) kivimilisest koosseisust ja fossiilide levikust Põhja-Eesti keskosas. Nelja uuritud läbilõike võrdlemisel ilmnes, et lademe paksuse kiire lõunasuunaline vähenemine (ligi kolm korda $25 \mathrm{~km}$ kohta) on tingitud vanemate kihtide järkjärgulisest väljakiildumisest. Läbitöötatud materjal lubab järeldada, et Oandu-ealised setted kuhjusid madalaveelises, rohkem või vähem suletud šelfi osas meretaseme muutlikes tingimustes. Baltoskandia paleobasseini, sealhulgas Põhja-Eesti Hilis-Keila- ja Oandu-ealiste setete ja faunakoosluste kujunemisel olid määravaks regionaalse ja globaalse ulatusega olulised keskkonnatingimuste muutused. Need muutused on võrreldavad ja tõenäoliselt enam-vähem üheaegsed oluliste muutustega Põhja-Ameerika paleobasseinis.

On esile tõstetud mõnede brahhiopoodide ja mikrofossiilide võimalik biostratigraafiline tähtsus Oandu lademe eristamiseks Lõuna-Eesti läbilõigetes, mis kuuluvad Skandinaavia fatsiaalsesse vööndisse. Oandu lademe eristamise kriteeriumid on nimetatud vööndi puhul seniajani diskuteeritavad. 


\title{
ОАНДУСКИЙ ГОРИЗОНТ В ЩЕНТРАЛЬНОЙ ЧАСТИ СЕВЕРНОЙ ЭСТОНИИ
}

\author{
Линда ХИНТС
}

В виде обзора рассмотрены литологический состав пород и распространение фауны в четырех разрезах оандуского горизонта центральной части Северной Эстонии. Выяснено, что сокращение мощности оандуского горизонта в южном направлении (примерно втрое на 25 км) происходило за счет выклинивания более древних слоев. Глинистые мергели и известняки горизонта формировались в условиях относительно мелкого и закрытого шельфа. Формирование позднекейласких и оандуских отложений, а также фаунистических сообществ происходило под влиянием существенных изменений среды, обусловленных региональными и глобальными факторами (трансгрессия, регрессия, изменение климата, топография дна бассейна и т. д.).

Обращено внимание на некоторые виды брахиопод и микрофоссилий, полезных с точки зрения корреляции резрезов в Северной и Южной Эстонии. В последнем регионе критерии разграничения оандуского горизонта пока остаются дискуссионными. 